\title{
Foreign Direct Investment (FDI) Inflows in Ghana: Sectorial Impact on Economic Growth (GDP)
}

\author{
David Prah \\ University of International Business and Economics, China
}

\begin{abstract}
Using a multiple regression analysis that includes FDI sector contribution and other macroeconomic variables, this paper explores the impact of FDI on economic growth in Ghana from sector perspective. From the analysis (the pair wise correlation), this study's findings indicate that FDI inflow into the tertiary sector, which involves Export trading, Service, Tourism, Liaison, General trading and Export trading, correlates and for that matter contributes to economic growth more than the secondary and the primary sectors. It is the case that for every unit increases in FDI inflow into the tertiary sector, GDP grows by as large about $85 \%$. The second highest FDI sector contributor to GDP growth is the secondary sector, which comprises mainly the manufacturing and building \& construction. This sector has about 67\% multiplier effect on economic growth. Last but not least, FDI inflows into the primary sector also influence economic growth by about 57\%. Both inflation and interest however has a deleterious impact on economic growth (GDP). As a matter of policy, this study recommends that policymakers and governments should put in much attention and resource in attracting FDI into the tertiary sector as well as reducing inflation and interest rate.
\end{abstract}

Keywords: FDI, Economic growth, Primary, GDP, Secondary and Tertiary Sector

\section{FDI Inflows and its Effects of FDI on Ghana's Economy}

Foreign Direct Investment (FDI) has enjoyed a respected position within a lot of countries. It is therefore not uncommon for policymakers to maintain that Foreign Direct Investment (FDI) promotes the actual productiveness of affected places and encourages growth. FDI has gradually become very important in most third-world countries around the globe, over the years, with most developing countries being successful in attracting large amounts of FDIs to enhance their economic performances. Most economic theories that relate FDI and economic growth have been able to propose a number of means through which FDI may influence the economy of the host nation. Mostly, these theories suggest that, the economic underlying for attracting FDI is from the conception that, foreign investment creates externalities, mostly in the form of technological transfers and spillovers. According to Romer (1993), there exist an important "idea gap" between developed and developing countries. He further claimed that foreign investment can enhance the transfer of technological and business knowledge to developing countries. According to Romer (1993), Foreign Direct Investment possibly, will enhance the growth and output of not only those enterprises which directly receive foreign investment, but all firms. This multiplier effect of substantial technological transfer, through FDI inflows, on the entire economy captures the spillover effect. Contrary to Romeres (1993) claim, (Boyd and Smith, 1992) maintained that, FDI under preexisting trade and other items like price, financial and other bottlenecks will impede the allocation of resources and hence retard economic growth. Thus, there are varying theories that link foreign direct investment and economic growth, based on policies and several extra prevailing economic conditions.

Most firm-level works of certain countries negate Romer's (1993) positive relationship of FDI and economic development. These studies do not also confirm the claimed positive spillovers that are supposed to be transferred from foreign investment to the local firms. Example, Aitken and Harrison ${ }^{\text {ee }}$ (1999) study found no such evidence of positive technological-spillover from foreign enterprises to the domestic or local firms in Venezuela for the years 1979 to 1989. As Blomstrom (1986) found that Mexican sectors with higher level of foreign ownership had faster growth in productivity, Haddad and Harrison (1993) however found no such growth-enhancing spillover evidence elsewhere. A summary by Lipsey and Sjoholm (1999) found that, researchers realized some positive spillovers in some industries; however, country-specific and industry-specific situations were so significant that the results were not in support of the general conclusion that FDI promotes substantial spillover effects in the entire economy. There have been lots of empirical reports, both academic and professional, on the nexus or connection between FDI and economic development. Few of such reports have been able to test the actual link between FDI and economic development. Among these writers, varying conclusions have been realized, based on the processes and the methodologies, the data, the time and the geographical areas used in their investigation. According to Carkovic and Levine (2006),

In support of this claim, (Borensztein, De Gregorio, and Lee (1998) and $(\mathrm{Xu}, 2000)$ maintained that FDI transfers technology, which results into higher growth which happens when the host country has a least possible starting point of human capital. Again, Alfaro, Chanda, Kalemli-Ozcan and Sayek (2004),

Durham (2004), and Hermes and Lensink (2003) offer evidences that countries that have developed their financial markets enjoys a considerable increase from foreign direct investments with respect to their growth rates. With emerging economies, Foreign Direct Investment (FDI) is well-thought-out to be a way to transfer technology and capital from other developing and particularly advanced countries. The proof are when FDI comes to a domestic 
country to a particular firm or business, that firm or business get competitive advantage as a result of the usage of new knowledge, experience, how production and management are carried out. According to $\mathrm{Yu}$ et al. (2011) FDI is deliberated to be one of the major ways transferring technology.

Nonetheless, other studies by Schoors et al., (2002) put forward that FDI can produce adverse consequences on local economies. For instance, foreign firms taken back their profit home and "market stealing effect" adversely affect economic growth. Mahutga et al. (2008) put forward that oversees investment also has a strong positive effect on income inequality; effect can be seen in the short term, despite how FDI was measured. FDI are diverse in its structure and as such Eller et al. (2006) put forward that the level and quality of foreign investment affects growth in emerging economies. Although the theoretical work on FDI mostly postulates a direct link between FDI and economic growth, it is worthwhile to indicate the channels through which FDI off-sets economic growth and also, the magnitude or the incidence of effect from these channels. Most of the macro empirical works that has analyzed the effects of aggregate FDI inflows-stocks on host economies does not, control for the sector in which FDI is involved.

In spite of the fact that it may appear to be regular to contend that foreign direct investment can pass on incredible favorable circumstances to host nations, such picks up strength vary significantly across primary, manufacturing, and services sectors. UNCTAD World Investment Report (2001:138), for instance, argues, "In the primary sector, the scope for linkages between foreign affiliates and local suppliers is often limited. The manufacturing sector has a broad variation of linkage intensive activities. In the tertiary sector, the scope for dividing production into discrete stages and subcontracting out large parts to independent domestic firms is also limited." The asymmetric sector impact of FDI, on economic growth is the very interest of this study. The research question is "Which sector-level FDI impact on Ghana's economic growth (GDP) much"? The purpose of this study is therefore to follow suit of the numerous existing studies that link foreign direct investment and economic growth, in any case, by looking at the part foreign direct investment inflows play in promoting growth through the main economic sectors, namely primary, secondary and tertiary. This study attempts to evaluate sector-effects of FDI, on the economic growth of Ghana. It again tries to empirically forecast which sector has the most significant impact on the growth of the economy and offer policy directions for all stakeholders involve.

Foreign Direct Investment (FDI) in developing economies has increased quickly after a change in their financial and political system. In order to surge their portion of FDI influxes, almost all the countries have relaxed their restraints on FDI, reinforced other factors such as economic stability, privatizing state-owned enterprises, introduced reforms in the domestic financial systems, capital account liberalization and granting tax holidays.

For example, Ghana via the Free Zones Act, 1995 as well as the Ghana Investment Promotion Act 1994, jointly allowed some tax benefits and investor protection plans to entice overseas investors and also provide favorable environs for business success. The above decision and plan that took resulted in large number of FDIs and assisted in economic growth. Per the World Bank's Doing Business team, drawing in FDI is a concern for Ghana by which Ghana came up with policies and economic reforms.

Several Governments in Ghana have come up numerous novel legislations to advance investment situations and the business climate so as to draw in FDI. The amount of FDI that came to Ghana in 2005 was $\$ 636 \mathrm{M}$. The figure quadrupled in 2006 and amounted to $19.4 \%$ of gross fixed capital formation according to 2008 World Investment Report (WIR).FDI flows from the year 2000 to 2013 have not been stable. FDI started picking up the year 2005 but fell in 2009 but again took a jump in 2010. As a matter of truth, UNCTAD reports that, from 2005 to 2006, US\$435 million FDI flows into Ghana tripled (World Bank, and IFC, 2008) adding that, the government has been vigorous refining the country's business environment and that, it has been among the top ten reformers worldwide for the second time in succession, World Bank's Doing Business report says (IBID). Ghana is a country gifted with naturally resource, this makes it hub to a mixed of sectors. Among them are agribusiness, tourism, manufacturing, infrastructure, and services and others. FDI as a whole is contributing massively to Ghana's economic growth and development (World Bank, and IFC, 2008). Foreign Direct investment, again, looks bright and strong due to the discovering of the oil and the coming into being the oil industry, since it is more likely to draw massive amounts of capital.

Foreign Direct Investment (FDI), is a key source of capital which comes up with modern technology. Domestic savings alone cannot generate this capital. Foreign Direct Investment produces more spillovers and that these spillovers are made available to the economy at large. Individual cooperation's cannot claim ownership of these benefits. They include specific technologies in production and distribution, together with industrial upgrading and a host of others.

Foreign direct investment that flows to the service sector disturbs the affected country's keenness by way of increasing the productivity of capital and letting the local country to influence capital on reasonable agreements (Lipsey, and Chrystal, 2007). The most recent worth for Foreign direct investment, net inflows (BoP, current US\$) in Ghana was $\$ 3,227,000,000.00$ starting 2013. In the course of recent years, the worth for this pointer has vacillated between $\$ 3,294,520,000.00$ in 2012 and $(\$ 18,260,970.00)$ in 1976 (International Monetary Fund). Foreign Direct Investment, net inflows (\% of GDP) in Ghana was 6.70 starting 2013. Its most astounding value in the course of recent years was 9.52 in 2008, while its least amount was - 0.66 in 1976(World Bank and OECD GDP estimates).By way of countries development and growing towards industrial nation position, foreign direct investment flowing into the country, it contributes to their more assimilation into the worldwide economy by way of bolstering foreign trade flows. On the face of it is that, a lot of factors are at play. They are the growth and establishment of international linkages of connected or seemingly enterprises and a growing reputation

\section{Volume 8 Issue 1, January 2019 www.ijsr.net}


of foreign subsidiaries in MNEs ${ }^{\text {ee }}$ plans for delivery, sales and marketing (André-Pascal, 2002). A lot of empirical works have been done over time and space, about the relationship of FDI and economic growth. Anowar and Mohammad (2011) looked at how foreign direct investment and economic growth interact in Bangladesh, Pakistan and India over the period of 1972 to 2008. The findings indicated that there is connection concerning foreign direct investment and the development of the economy in Bangladesh and India yet there is a positive relationship between FDI and development in Pakistan.

Then again the causality test demonstrated that there is no directional causality between GDP and foreign direct investment for Bangladesh. Antwi et al. (2013) studies the impact of FDI on growth. They employed simple OLS regressions and confirmed a positive and significant relationship between FDI and growth. However, the study failed to check for directional causality between the two variables. Ayanwale (2007) explored the empirical link involving foreign direct investment in the non-extractive industry and economic growth in Nigeria. Using ordinary least square technique, the study came out that foreign direct investment are positively correlated. Balasubramanyam et al (1996) analyzes in what way FDI results in the growth of an economy especially in emerging nations. By means of crosssection data and ordinary regression model regressions he finds that FDI produces a positive result on economic growth in the affected countries employing an export promoting approach but do not takes happen in nations who have adopted an import substitution method. Borensztein et al. (1998) tested the correlation between FDI and GDP in a cross-country regression framework with sixty nine developing countries over two separate time-periods 19701979 and 1980-1989. They found that the result of FDI on development relies on upon the level of human capital in the recipient nation and that foreign direct investment has positive development impacts just if the level of training is higher than a given limit. Thus, the findings of Borensztein et al support the results of Borensztein et al that FDI positively affects growth. However, both studies failed to check for directional causality between the two variables. Chukwaka et al. (2012) investigated the connection between foreign direct investment and gross domestic product growth in Nigeria using annual time series data spanning the period 1960 to 2010. They used also used the Johansen test and the Granger causality approach and find a positive and a major connection among foreign direct investment and growth and a two way directional causality from the variables.

Edoumiekumo (2009) employed the Johansen co integration approach to investigate the link concerning FDI and growth of the economy in Nigeria. The study established a progressive and major relationship among foreign direct investment and development. Hansen and Rand (2005) analyzed the casual link between foreign direct investment and gross domestic product. They found a unidirectional causality between FDI to GDP ratio suggesting that foreign direct investment causes growth. In addition, Johnson (2006) modeled the potential of FDI inflows to affect host country economic growth. The study discovered that foreign direct investment inflows add to economic growth. Therefore, the findings of Johnson harmonize with Hansen and Rand that
FDI and growth are positively related and that FDI spurs growth. Herzer et al. (2008) also, revisited the foreign direct investment directed growth proposition for twenty eight countries. The study discovered that there is no connection among foreign direct investment and economic growth. AbdusSamad (2009) contended with Herzer et al when he analyzed the link concerning FDI and growth of the economy for nineteen emerging countries of South-East Asia and Latin America.

The results confirmed a one way direction causality that runs from economic growth to foreign direct investment. In addition, the researcher reported a two-way causal affiliation including foreign direct investment and monetary development. In conclusion, a one way directional short run causal connection that tracks from economic development to foreign direct investment wasalso found. Loesse et al. (2010) examined the linkage and directional causality between FDI and growth of ten Sub-Saharan African countries using yearly time series data from 1970 to 2007 . They and realized a positive and significant correlation between FDI and GDP growth in Angola, Liberia, Kenya and South Africa. However, they found a one way connection coming from FDI to GDP growth. Both Loesse et al and Ogiagah et al. have the same opinion on the correlation concerning foreign direct investment plus growth. However, the difference in directional causality could be due to the difference in methodology. Annual time series and panel data may not yield the same results. Lastly the two econometric techniques- Granger causality and Toda and Yamomanto could also yield the different results. Nair-Reichert and Weinhold (2001) test causality for cross country panels. They discovered that foreign direct investment typical has a major influence on growth, though the correlation is extremely mixed across countries. Obiamaka and Onwumere (2011) ascertained the extent to which growth in foreign direct investments (FDIs) impacts economic growth in Nigeria over the period 1980 to 2007 using annual time series data. The findings indicated that foreign direct investment had negative consequences on economic growth in Nigeria. The result further shows that foreign direct investment is only significant when combined with stock market indices. The findings of Saibu et al contradict that of Obiamaka and Onwumere. This could be attributed to the difference in methodology.

The Johansen Co-integration test and the Autoregressive Distributed Lag (ARDL) technique yield variation in the results. However, both studies fail to check for causality between foreign direct investment and growth in Nigeria. Okodua (2009) analyzed the actual sustainability regarding FDI-growth nexus with Nigeria. Folorunso (2013) used rho"s rank correlation along with causality check throughout researching this feasible links involving FDI and economic development in Nigeria. The actual end result discovered how the link among foreign direct investment and economic growth or development in Nigeria is usually positive however poor (Edoumiekumo 2009). Ogiagah et al. (2010) considered the linkage between foreign direct investment and GDP growth in Nigeria using annual time series data from 1970 to 2007 of the Sub-Sahara Africa Region. The study revealed a positive association among foreign direct investment and GDP growth.Quiser et al. (2011) studied the

\section{Volume 8 Issue 1, January 2019




\section{International Journal of Science and Research (IJSR) \\ ISSN: 2319-7064}

Impact Factor (2018): 7.426

effect of foreign direct investment on Growth of South Asian Association for Regional Cooperation countries. The findings of Quiser et al conflict with that of Anowar and Mohammad because of difference in methodology, data and sample size.

Sajib et al. (2012) also analysed the role of foreign direct investment and trade on the growth in Pakistan by employing the Simple Least Square Method using yearly time series data as of 1990 to 2008. The results indicated a positive and statistically insignificant association between inflation and FDI. Shumaila et al. (2012) agreed with Sajib et al. (2012) when they took a step further to study the impact of capital inflows on domestic inflation in Pakistan over the period 1980 to 2010 using co integration test and error correction model. However, their findings conflict the work of Djokoto (2012) who studied the influence of investment promotion on foreign direct investment inflow in Ghana over the period 1970 to 2009 and discovered a negative relationship between inflation and FDI. Sackey et al., (2012) employed various econometric tools such as Augmented Dickey Fuller tests to study the effect of foreign direct investment on economic growth of Ghana using time series data from 2001 to 2010. Sumei Tang et al. (2008) test the causative relationship involving foreign direct investment in the host county in addition to the growth of the economy in China from the period 1988-2003. Their work established a one directional causation beginning foreign direct investment to economic growth. The researchers came out that foreign direct investment has aided in mobilizing capital, as well as speeding up economic growth via adding to local investment in China.

Zhang (2001) as well as Choe (2003) looks at the real causality involving FDI along with economic/financial growth. Zhang employs data pertaining to 11 developing countries or nations around the world throughout Asian countries along with Latin America. Zhang (2001) discovers that throughout a few circumstances economic development is actually boosted by means of FDI however host nation problems such for instance industry/business program as well as macroeconomic security are essential important. Based on the results involving Choe (2003), causality among economic or financial development and also FDI extends within both routes nevertheless having a propensity in the direction of development/progress triggering FDI; there is certainly minor proof in which FDI cause host nation growth/development. Swift economic or financial development could cause a rise with FDI inflows.
There exists a more research carried out throughout by Chowdhury and Mavrotas (2003) which in turn analyze the actual link concerning foreign direct investment together with financial development utilizing a modern econometric methodology to examine the actual direction or path involving causality relating to the a couple of parameters or factors. Zakia along Ziad (2007) likewise assessed the result involving FDI and economic/financial growth/development involving Jordan. The actual predicted regression outcomes indicated towards the existence associated with bidirectional relationship among FDI along with result.

\section{Methods and Discussion}

The study uses annual secondary data over the periods of 2001 and 2013. In line with the study's objective of appreciating the sector impact of FDI on economic growth, the researcher further purposefully blocks the default segments of economic growth contribution (Agriculture, Building \& Construction, Export Trading, General Trading, Liaison, Manufacturing, Service and Tourism) into yet three broad cohorts, namely the Primary, Secondary and Tertiary. The underlying of the blockings is based on the level of production, in the production hierarchy. The Primary block captures the Agricultural sector, the Secondary block is made up of the Manufacturing and Building \& Construction and whiles the Tertiary block consists of Export trading, Service, Tourism, Liaison, General trading and Export trading. The FDI data is taken from GIPC. Data on the response variable and the other macroeconomic variables are taken from the Bank of Ghana data source.The FDI data was per annum secondary data over the periods of 2001 and 2013.The FDI data which were taken from GIPC, was measured in millions of US dollars (\$US) and was further blocked into the three main segments namely; primary, secondary and tertiary GDP data was taken from World Bank.

The inflation data was also taken from the World Bank. Inflation was measured by the consumer price index and reflects the annual percentage change in the cost to the average consumer of acquiring a basket of goods and services that may be fixed or change at specified intervals such as yearly. Per the World Bank, the Laspeyres formula was generally used. The interest rate was taken from Bank of Ghana and was based on the monetary policy rate (MPR). Both inflation and interest rate will have negative effect on GDP.

Table 1: Descriptive Statistics of Variables

\begin{tabular}{|c|c|c|c|c|c|}
\hline Variable & OBS & MEAN & STD. DEV. & MIN & MAX \\
\hline PRI & 14 & 91640265.9085714 & 153021578.099358 & 4278018 & 512591048.5 \\
\hline SEC & 14 & 1666508056.71 & 2198391219.56824 & 14855441.5 & 6425438390.3 \\
\hline TER & 14 & 414813132.693571 & 457504259.58025 & 19110352.72 & 1442189840.66 \\
\hline GDPg & 14 & 21832020685.3564 & 14958363713.004 & 4982849016.25228 & 48584737986.797 \\
\hline Interest rate & 14 & 18 & 5.09902 & 12.5 & 27 \\
\hline Inflation & 14 & 16.06835 & 7.385951 & 27 & 32.90541 \\
\hline
\end{tabular}

Table one presents a description of the variables in the growth model. It is apparent that the study used a wellbalanced data, without any missing values, as equal observations are seen for all variables. 14 observations were used in each variable for the analysis. 


\begin{tabular}{c|cccccc} 
& PRI & SEC & TER & GDP & gintere $~$ & Inflation \\
\hline PRI & 1.000 & & & & & \\
SEC & 0.4499 & 1.0000 & & & & \\
TER & 0.4569 & 0.4009 & & & & \\
GDPg & 0.5770 & 0.6755 & 0.8529 & 1.0000 & & \\
Interest Rate & -0.4626 & -0.6217 & -0.4265 & -0.7065 & 1.0000 & \\
Inflation & -0.4122 & -0.5926 & -0.4145 & -0.6570 & 0.8361 & 1.0000
\end{tabular}

The primary sector, which involves only the agricultural sector, has been indicated by this study, to have the least positive returns or correlation on economic growth. It has about $57 \%$ positive correlation with GDP. With the agricultural sector receiving the least FDI inflow taken into consideration the time frame for this study, it is not surprising that its contribution is also the least. Per the objectives of this study, the allocation of FDI to the primary sector relatively has the least impact on economic growth among the three sectors. The secondary sector, as defined by this study comprises the manufacturing and building \& construction. It correlates positively with GDP. Even though the FDI into the secondary sector was the highest among the all the three sectors, however, its contribution was lower comparing with the tertiary which impact GDP most but its FDI inflow is not equal to that of the secondary sector. The reason that account for such low impact even though its receives the most inflows could be as a result of inefficiencies at that sector. Nonetheless as earlier on indicated in the literature, FDI to manufacturing sector has much larger potential to affect the recipient economy as the linkages to the recipient economy are better defined. The literature further explained that foreign firms in manufacturing sector invest rather than export to a country for either efficiency-seeking or market-seeking or a combination of both. It is to be expected that FDI will to bring in the technology together with innovations that will be well-suited to the country when FDI is efficiency-seeking only. It usually generates significant employment and provides training. It is there not uncommon to have inflows of FDI into the secondary sector churning out such positive results.FDI allocation into the tertiary sector, which this study defined to encompass the Export trading, Service, Tourism, Liaison, General trading and Export trade, also significantly correlates positively with (GDP) the growth of the economy. It has been indicated by this study, to have as large as about $85 \%$ positive returns or correlation with economic growth. Per the research objective, the tertiary sector has the largest contribution to GDP. FDI inflows into these areas are necessary to enhance technology to improve capacity and quality; and altogether lower the cost of services. The acquisition of certain state-owned companies in the country, including banks, by foreign investors, has had important impacts both on the efficiency and stability, through increased competition and access to large capital. All these may be the reasons for the stipulated $85 \%$ significant influence of FDI in the tertiary sector, on the economy. This sector has a multiplier effects on the previous two sectors. All sectors in the economy depend on the efficiency of the service providing agencies in the economy. Even though, FDI into the tertiary sector is lower than that of the secondary sector, its impact is more than that of the secondary. This could be that, the tertiary sector is efficient because of technology employed.
The study shows that inflation and interest rate has a significant inverse correlation or relationship with economic growth. Both inflation and interest rate are likely to retard economic growth. Inflation together with interest is a function GDP. An increase in inflation will have an adverse effect on GDP, same applies to interest rate. Such inflationary behaviors create uncertain economic environment and makes it difficult for economic agents to extract correct signals from relative prices (Barro, 1976 and 1980). By creating uncertain economic environment, such inflationary rate reduces the expected return to investment and so as the volume of investment. As Asiedu (2006) puts it, African countries with high inflation rate attract less FDI. This result is also in congruence with, Basu and Srinivasan (2002). As discussed in the literature, stabilized macroeconomic stability is one of the factors that render country's attractive to FDI. Braga et al. (2009), in their assessment in the determinants of Chinese direct investment in Africa compared with those of global FDI unveiled that macroeconomic stability (measured by low inflation rate) is positively correlated with Chinese and global FDI in Africa. Thus stakeholders should be concerned about inflation.

\section{Conclusion, Recommendation and Further Research}

This study sought to evaluate the impact of FDI sector inflows on economic growth. The study conveniently blocked the Agriculture, Building \& Construction, and Export Trading, General Trading, Liaison, Manufacturing, Service and Tourism segments into primary, secondary and tertiary sectors. FDI inflow into the primary (agricultural sector) influences economic growth by about $57 \%$, the secondary sector (manufacturing and building \& construction), with about $67 \%$ influence on economic growth. The highest determinant of economic growth, based on the data is the tertiary sector (Export trading, Service, Tourism, Liaison, General trading and Export trading), which impacts economic growth by about $85 \%$. All the sectors correlate positively with GDP. Other macroeconomic determinants like inflation have an inverse relationship with economic growth. Our results offer some support for the possible diverse impacts of sector-level FDI with respect to promoting growth. From the results of the study, the researcher proposed the following. The researcher therefore recommends that government and policy makers divert attention and much resource in attracting more FDI into the tertiary sector. Policy makers should take calculated measures in addressing or bringing inflation down since inflation has a significant inverse relationship with economic growth.

Inflation reduces the expected return to investment and so as the volume of investment via creating uncertain economic 


\section{International Journal of Science and Research (IJSR) \\ ISSN: 2319-7064}

Impact Factor (2018): 7.426

environment and makes it difficult for economic agents to extract correct signals from relative prices (Barro, 1980). As put it out by Basu and Srinivasan (2002), African countries with high inflation rate attract less FDI. Stakeholders should make an attempt to reduce inflation so as to bring in more FDI since more FDI spur up economic growth. We can see that, FDI into the secondary sector even though correlates positively with GDP, its impacts are not as expected even though it receive the highest FDI inflows. The inefficiencies should be removed so that the real and expected impact can be met or felt. Rather government should be more concern on macroeconomic factors since they are expected to attract FDI as confirm by (Asiedu 2006, and by Basu and Srinivasan 2002).

\section{References}

[1] Asiedu, E. (2002) On the determinants of foreign direct investment to developing countries: is Africa different?.World development, 30(1), 107-119.

[2] Asiedu, E. (2006). Foreign direct investment in Africa: The role of natural resources, market size, government policy, institutions and political instability.The World Economy, 29(1), 63-77.

[3] Agbloyor, E. K., Abor, J., Adjasi, C. K. D., \&Yawson, A.(2013). Exploring the causality links between financial markets and foreign direct investment in Africa.Research in International Business and Finance, 28, 118-134.

[4] Agénor, P. R (2004).The economics of adjustment and growth. La Editorial, UPR..

[5] Aitken, B. J., \& Harrison, A. E. (1999).Do domestic firms benefit from direct foreign investment? Evidence from Venezuela.American economic review, 605-618.

[6] Alfaro, L. (2003).Foreign direct investment and growth: Does the sector matter Harvard Business School, 1-31.

[7] Alfaro, L., Chanda, A., Kalemli-Ozcan, S., \&Sayek, S. (2004). FDI and economic growth: the role of local financial markets. Journal of international economics, 64(1), 89-112.

[8] Antwi, S., Mills, E. F. E. A., Mills, G. A., \& Zhao, X. (2013).Impact of foreign direct investment on economic growth: Empirical evidence from Ghana. International Journal of Academic Research in Accounting, Finance and Management Sciences, 3(1), 18-25.

[9] Arezki, R., Candelon, B., \&Sy, A. N. R (2011). Sovereign rating news and financial markets spillovers: Evidence from the European debt crisis. IMF working papers, 1-27.

[10] Ayanwale, A. B.(2007).FDI and economic Growth: Evidence from Nigeria

[11] Balasubramanyam, V. N., Salisu, M., \&Sapsford, D. (1999).Foreign direct investment as an engine of growth. Journal of International Trade \& Economic Development, 8(1), 27-40.

[12]Barro, R., \& Martin, S. I. X.(1995).Economic growth. Boston, MA.

[13] Berthélemy, J. C., \&Demurger, S. (2000). Foreign direct investment and economic growth: theory and application to China. Review of development economics, $4(2), 140-155$.
[14]Blomström, M. (1986).Foreign investment and productive efficiency: the case of Mexico. The Journal of Industrial Economics,97-110.

[15] Blomström, M., Kokko, A., \&Mucchielli, J. L. (2003).The economics of foreign direct investment incentives Springer Berlin Heidelberg, 37-60

[16] Borensztein, E., De Gregorio, J., \& Lee, J. W. (1998).How does foreign direct investment affect economic- growth?.Journal of international Economics, 45(1), 115-135.

[17] Boyd, J. H., \& Smith, B. D. (1992). Intermediation and the equilibrium allocation of investment capital: Implications for economic development. Journal of Monetary Economics, 30(3), 409- 432.

[18] Chakraborty, C., \&Nunnenkamp, P. Economic reforms, foreign direct investment and its economic effects in India (No. 1272).KielerArbeitspapiere, 2006.

[19] Choe, J. I. Do foreign direct investment and gross domestic investment promote economic growth?.Review of Development Economics, 2003, 7(1), 44-57.

[20] Chowdhury, A., \&Mavrotas, G. (2003).Foreign Direct Investment and Growth: What Causes What.Department of Economics, Marquette University.

[21] Deichmann, J., Karidis, S., \&Sayek, S. (2003).Foreign direct investment in Turkey: Regional determinants.Applied Economics,35, 1767-1778.

[22] Dimelis, S. P. (2005).Spillovers from foreign direct investment and firm growth: Technological, financial and market structure effects. International Journal of the Economics of Business, 12(1), 85-104.

[23] Djokoto, J. G. (2012).The effect of investment promotion on foreign direct investment inflow into Ghana. International Business Research, 5(3), 46.

[24] Dollar, D., \&Kraay, A. Trade, growth, and poverty.The Economic Journal, 2004 114(493), F22- F49

[25] Dupasquier, C., \&Osakwe, P. N. (2006). Foreign direct investment in Africa: Performance, challenges, and responsibilities. Journal of Asian Economics, 17(2), 241260.

[26] Durham, J. B. Absorptive capacity and the effects of foreign direct investment and equity foreign portfolio investment on economic growth.European economic review, 2004 48(2), 285-306.

[27]Eller, M., Haiss, P., \& Steiner, K. Foreign direct investment in the financial sector and economic-growthin Central and Eastern Europe: The crucial role of the efficiency channel. emerging Markets review, 2006,7(4), 300-319.

[28] Findlay, R. Relative backwardness, direct foreign investment, and the transfer of technology: a simple dynamic model. The Quarterly Journal of Economics, 1978 1-16.

[29] Girma, S., Kneller, R., \&Pisu, M. Exports versus FDI: an empirical test. Review of World Economics, 2005.141(2), 193-218.

[30] Globerman, S., \& Shapiro, D. Governance infrastructure and US foreign direct investment.Journal of International Business Studies, 2003.34(1), 19-39

[31] Grossman, G. M., \&Helpman, E. Trade, Innovation, and growth.The American economic review, 1990,86-91.

[32] Haddad, M., \& Harrison, A. (1993).Are there positive spillovers from direct foreign investment?: Evidence

Volume 8 Issue 1, January 2019

www.ijsr.net

Licensed Under Creative Commons Attribution CC BY 
from panel data for Morocco. Journal of development economics, 42(1), 51-74.

[33] Hansen, H., Rand, J., \& Tarp, F. (2009). Enterprise growth and survival in Vietnam: does government support matter?.The Journal of Development Studies, 45(7), 1048-1069.

[34]Hejazi, W., \&Safarian, A. E. (1999).Trade, foreign direct investment, and $\mathrm{R} \& \mathrm{D}$ spillovers.Journal of International Business Studies, 491-511.

[35] Henrik Hansen (2006). On the Causal Links Between FDI and Growth in Developing Countries, The World Economy

[36] Hermes, N., \&Lensink, R. (2003).Foreign direct investment, financial development and economic growth. The Journal of Development Studies, 40(1), 142-163.

[37] Herzer, D., \&Klasen, S. (2008). In search of FDI-led growth in developing countries: The way forward. Economic Modelling, 25(5), 793-810.

[38] International Monetary Fund (IMF). (2002). World Economic Outlook: A Survey by the Staff of the International Monetary Fund-October 2002 International Monetary Fund.

[39] Jonathan Batten (2008). An analysis of the relationship between foreign direct investment and economic growth", Applied Economics, Journal of International Trade Law and Policy,12(1), 2013- 05-27

[40] Kinda, T. (2010). Investment climate and FDI in developing countries: firm-level evidence. World development, 38(4), 498-513.

[41] Kokko, A. (1994). Technology, market characteristics, and spillovers.Journal of development economics, 43(2), 279-293.

[42] Krugman, PR, \&Obstfeld, M. (2009).International Economics: Theory and Policy of Foreign Trade.Pearson Germany GmbH.

[43]Lipsey, R. E., \&Sjöholm, F. (2005). The impact of inward FDI on host countries: why such different answers?.Does foreign direct investment promote development, 23-43.

[44]Lipsey, R. G., \& Chrystal, K. A. (2007).Economics Oxford University Press.

[45] Mishal, Z., \&Abulaila, Z. (2007). The impact of foreign direct investment and imports on economic growth: The case of Jordan. Journal of Economic and Administrative Sciences, 23(1), 1-31.

[46] Mohamed, S. E., \&Sidiropoulos, M. G. (2010). Another look at the determinants of foreign direct investment-in MENA countries: an empirical investigation. Journal of Economic Development, 35(2), 75-95.

[47] Muhammed, O. Z., Fatima, P. I., \&Omade, S. I. (2011).Co-integration Analysis of Foreign Direct Investment Inflow and Development in Nigeria.Developing Country Studies, 1(1), 56- 66.

[48] Muktadir-Al-Mukit, D., Shafiullah, A. Z. M., \&Sajib, A. H.(2013).Determination of Causality between Remittance and Import: Evidence from Bangladesh.International Journal of Business,andSocial Research, 3(3), 55-62.

[49] Musila, J. W., \&Sigué, S. P. (2006).Accelerating foreign direct investment flow to Africa: from policy statement to successful strategies. Managerial finance, 32(7), 577-593.
[50] Nair-Reichert, U., \&Weinhold, D. (2001).Causality Tests for Cross-Country Panels: a New Look at FDI, and Economic Growth in Developing Countries.Oxford bulletin of economics and statistics,63(2),153- 171.

[51] Ndikumana, L., \&Verick, S. (2008). The linkages between FDI and domestic investment: Unravelling the developmental impact of foreign investment in Sub-Saharan Africa. Development Policy Review, 26(6), 713-726.

[52] Okodua, H. (2009).Foreign direct investment and economic growth: Co-integration and causality analysisof Nigeria. African Finance Journal,11(1), 54-73.

[53]Romer, P. (1994).New goods, old theory, and the welfare costs of trade restrictions.Journal of development Economics,.43(1), 5-38.

[54] Romer, P. M. (1990).Human capital and growth: theory and evidence. InCarnegie-Rochester Conference Series on Public Policy (32),251-286).

[55]Rotjanapan, A. (2005)Topics in Foreign Direct Investment. The University of Kansas (Doctoral dissertation, Doctoral Dissertation submitted to the Department of Economics, University of Kansa, USA),

[56] Sackey, F. G., Compah-Keyeke, G., \&Nsoah, J. (2012).Foreign direct investment and economic growth in Ghana. Journal of Economics and Sustainable Development, 3(10), 120-133.

[57] Saqib, D., Masnoon, M., \&Rafique, N. (2013).Impact of foreign direct investment on economic growth of Pakistan.Advances in Management \& Applied Economics, 3(1), 35-45.

[58] Schoors, K., \& Van Der Tol, B. (, 2002).Foreign direct investment spillovers within and between sectors: Evidence from Hungarian data. Working Papers of Faculty of Economics and Business Administration, Ghent University, Belgium, 157.

[59] Tang, S., Selvanathan, E. A., \&Selvanathan, S. (2008)Foreign direct investment, domestic investment and economic growth in China: a time series analysis. The World Economy, ,31(10), 1292- 1309.

[60] Unctad. Commerce and development report 2002. In Report of the United Nations Conference on Trade-and Development. United Nations, New York and Geneva, 2002,58-68.

[61] UNCTAD.(2008). Development Report 2008.New York and Geneva, 31-40.

[62] Wang, J. Y., \&Blomström, M. (1992).Foreign investment and technology transfer: A simple model. European economic review, 36(1), 137-155.

[63] Woodward, D. P., \& Rolfe, R. J. (1993). The location of export-oriented foreign direct investment in the Caribbean Basin.Journal of international business studies, 121-144.

[64] World Bank Group (Ed.). World development indicators 2012.World Bank Publications, (2012).

[65] Yasin, Kashif and Ramzan, Muhammad. (2013).The Impact of Foreign Direct investment on Pakistan Economic Growth, Interdisciplinary Journal of Contemporary Research in Business. 